Gerión. Revista de Historia Antigua

ISSN: 0213-0181

https://dx.doi.org/10.5209/geri.74793

\title{
A Marble Head of Ares in the Old Archaeological Museum of Chalkis in Euboea, Greece ${ }^{1}$
}

\author{
Ruth Ovadiah²; Asher Ovadiah ${ }^{3}$
}

Recibido: 17 de julio de 2020 / Aceptado: 13 de marzo de 2021

\begin{abstract}
This study engages with a marble head of Ares, currently on exhibition at the Old Archaeological Museum of Chalkis in Euboea, Greece. The head has been executed according to the finest tradition of Classical-Hellenistic Greek sculpture, creating a figure with theatrical and pathetic expressions, recalling the Skopadic trend. The lack of pupils may indicate that the head of the god is a pre-Hadrianic Roman copy of a Greek original from the $4^{\text {th }}-2^{\text {nd }}$ centuries BCE.

Keywords: Attica; Pre-Hadrianic; Pupils; Sfumato; Skopas; Skopadic.
\end{abstract}

\section{[es] Una cabeza de mármol de Ares en el Antiguo Museo Arqueológico de Calcis, Eubea (Grecia)}

Resumen. Este estudio se ocupa de una cabeza de mármol de Ares, actualmente exhibida en el Antiguo Museo Arqueológico de Calcis, en Eubea (Grecia). La cabeza fue ejecutada de acuerdo con la mejor tradición de la escultura griega clásico-helenística, creando una figura con expresiones teatrales y patéticas que recuerdan el estilo de Escopas. La ausencia de pupilas puede indicar que la cabeza del dios corresponde a una copia romana, pre-adrianea, de una obra griega original de los siglos IV-II a.C. Palabras clave: Ática; pre-adrianeo; pupilas; sfumato; Escopas; estilo de Escopas.

Summary: 1. Introduction. 2. Iconography and discussion. 3. Dating. 4. References.

Cómo citar: Ovadiah, R.; Ovadiah, A. (2021): A Marble Head of Ares in the Old Archaeological Museum of Chalkis in Euboea, Greece, en Gerión 39/1, 295-301.

\footnotetext{
1 We are grateful to Dr. Demetrios N. Christodoulou, Head of the Department of Prehistoric and Classical Antiquities of the Superintendency of Antiquities of Euboea, Greece, for the kind permission (given on March $20^{\text {th }}, 2019$ ) to study and publish this head. We also wish to thank Ms. Sofia Katsali of the same Department, who kindly provided us with informative details about the marble head.

2 Israel Antiquities Authority.

E-mail: asher.ovadiah@gmail.com

3 Tel Aviv University.

E-mail: asher.ovadiah@gmail.com
} 
Ares, exceeding in strength, chariot-rider, goldenhelmeted, doughty in heart, shield-bearer, Saviour of cities, harnessed in bronze, strong of arm, unwearing, mighty with the spear. ${ }^{4}$

\section{Introduction}

The marble head of a Greek deity, discovered in Chalkis (in a field once owned by the Zerva family and today occupied by social housing), is currently on exhibition in the old archaeological museum of the city (Fig. 1). ${ }^{5}$ The provenance of the marble is probably Attica (if correct, the quarries would have been those of Mount Pentelicon).

The high artistic quality, visible in the treatment of the facial features, indicates that the head was sculpted in a workshop by a skilled artist, either in Chalkis or in its vicinity.

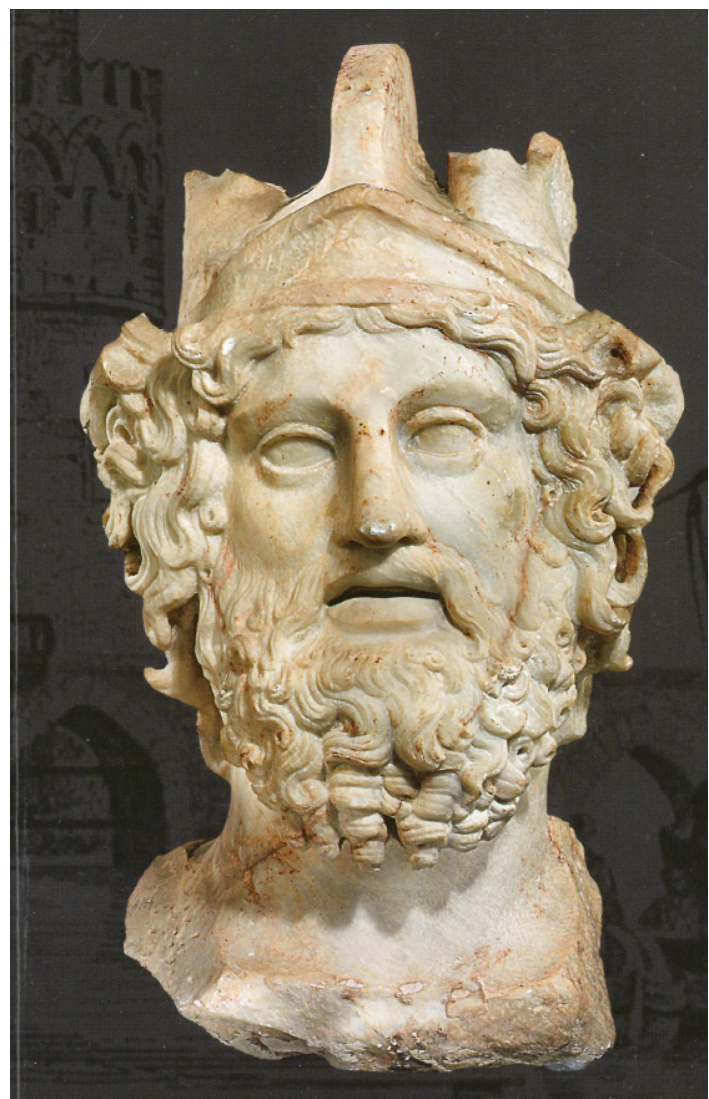

Fig. 1. Front view of the head (Kalamara et alii 2015, cover image)

$4 \quad$ The Homeric Hymns, VIII.1-3: To Ares.

5 This sculpted marble head is published here for the first time. Its photograph appears in Kalamara - Kosma Boukaras - Chairetakis 2015, 51 (Fig. 54 and illustration on front cover) without any discussion. Height - ca. $60 \mathrm{~cm}$; inventory number: MX 4164. 


\section{Iconography and discussion (Figs. 2-5)}

From the iconographic aspect, the following facial characteristics are prominent: the mouth is slightly open, creating an optical illusion of the oral cavity, while the teeth in the upper row are depicted in a hazy (sfumato) form; the mustachioed upper lip is slightly arched, and the lower lip is wide, thick and fleshy; the chin is hidden beneath the full, heavy beard; the cheeks are full and rather wide and the cheekbones are subtle; the almond-shaped eyes, lacking pupils, are not deeply set in their sockets and their contour is pronounced; the arched eyelids are emphasized with a groove, establishing a transition to the smooth and rather stylized eyebrows, rendered through an arched line; the forehead is smooth and broad; the bridge of the nose forms a continuous, straight line from the forehead, as is usual in Classical Greek sculpture of the $5^{\text {th }}$ and $4^{\text {th }}$ centuries BCE; ${ }^{6}$ drill marks are discernible in the beard, the locks of hair and the nostrils of the figure.

The head is executed according to the finest tradition of Classical-Hellenistic Greek sculpture. The artist has rendered the face as a man of intermediate age, with a facial expression transmitting a sense of tranquility and fulfilment. The artistic execution of the head reflects the hallmarks of a realistic tendency, as if representing an ordinary warrior, despite certain Classical idealistic features, such as the lack of pupils $^{7}$ and the continuous, straight line of the bridge of the nose from the forehead. The face receives emphasis through its surfaces, which create light and shade, resulting in a three-dimensional expression that contributes to enhancing the realistic character of the head.

The enlarged opening of the eyes (the wide 'Skopadic eye'), the 'baroque' execution of the locks of hair and the slightly open mouth, with the wide lower lip and the sfumato depiction of the upper row of teeth, together create an image with a pathetic expression that recalls the works of Skopas. ${ }^{8}$ Furthermore, the Skopadic technical-stylistic approach to rendering the eyes is intended to enhance the dramatic and pathetic character of the face. The locks of hair in disarray, the facial features, ${ }^{9}$ as well as the slightly raised head, by means of which the artist achieved a theatrical effect of the image, typical of the 'baroque' trend of the $3^{\text {rd }}-2^{\text {nd }}$ centuries BCE, strengthen the impression that the sculptor was influenced by the Skopadic-pathetic school. The lack of pupils ${ }^{10}$ creates the impression of an unfocused gaze of a daydreamer. This particular feature constitutes a chronological criterion, possibly indicating that the terminus ante quem of the head is pre-Hadrianic.

Cf. de Ridder - Deonna 1927 (1968), Pl. XIV; Lullies - Hirmer 1960, Pls. 117, 123, 132, 135, 137, 138, 141, 152, 153, 186, 225; Lawrence 1972, 280.

See, for example, Müller 1973, passim; Richter 1984, passim; Johansen 1992, passim.

Cf. Bieber 1967, 24-29, Figs. 54-57, 58-60, 62-63, 66-73; Avi-Yonah 1969, 150f.; Stewart 1977, 73-74, Pls. 24a (head), 25d (Leda), 30a-b (herm), 52 (lips: 2-5, eyes: 1, 4-6).

9 For similar facial features in the Greek sculpture, see: Bieber 1967, Figs. 531 (Laocoon), 581 (old centaur), 666 (head of Anytos), 771-773, 775-776 (heads of Zeus); Müller 1973, Ills. 20-21, 26 (the Great Altar of Pergamon, $2^{\text {nd }}$ century BCE); Smith 1991, Ills. 35 (Homer, copy after an original of $c a .200$ BCE), 37 (Unidentified philosopher, copy after an original of $3^{\text {rd }}$ century BCE), 64 (Zeus from Otricoli, $1^{\text {st }}$ century CE, based on an early Hellenistic type), 133/2 (Menelaus, copy after an original of $c a$. 250-200 BCE), 143 (Laocoon, copy after an original of $c a .200 \mathrm{BCE}$ ), 161 (old centaur, copy after an original of late $3^{\text {rd }}$ or $2^{\text {nd }}$ century BCE); Ridgway 2001, Pls. 57 (colossal Sarapis), 69c (head of Zeus, $3^{\text {rd }} 2^{\text {nd }}$ century BCE, but probably Roman).

10 See above, n. 7. 
The triangular brim of a crested helmet, an attribute of the god Ares, is prominent above the forehead, partially covering the locks of hair. The brim rises up the sides of the forehead in straight lines, gradually narrowing. The temples are adorned with curls on both sides. Two broken sphinxes or griffins are symmetrically sculpted on either side of the crested helmet. Based mainly on the triangular brim of the crested helmet, and perhaps also on the two broken sphinxes or griffins that decorate it, the head can be identified with the figure of Ares/Mars, ${ }^{11}$ whose image was quite frequent in both Greek ${ }^{12}$ and Roman ${ }^{13}$ sculpture. Furthermore, the literary sources relating to Skopas reveal that the sculptor had created a colossal seated statue of the god, ${ }^{14}$ but this has not survived.

An examination of the head rises several problems concerning its form and original location. However, since the head is broken off below the neck, it is difficult to determine whether it was once part of a larger-than-life statue or, alternatively, it is simply a broken bust. In addition, the back of the head is rough, barely treated, which may indicate that it was placed in a niche, either as a statue or a bust.

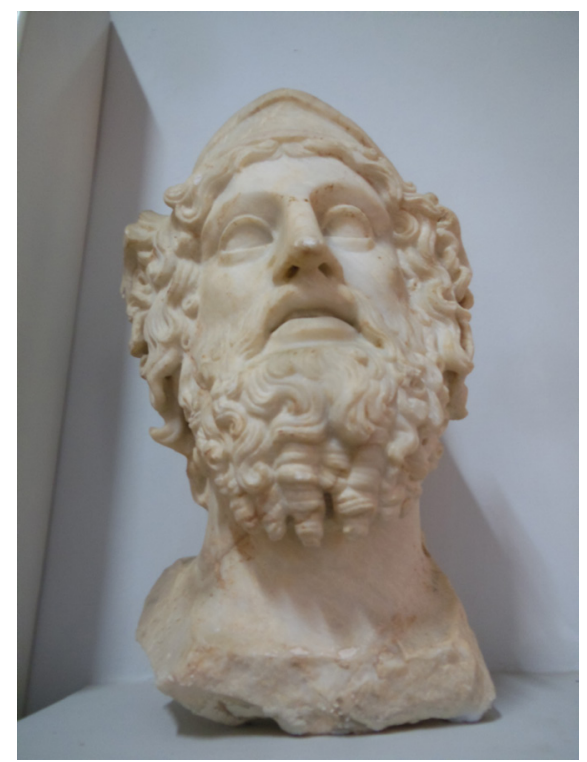

Fig. 2. Front view of the head at a different angle of photography (Asher Ovadiah; courtesy of the Superintendency of Antiquities of Euboea, Greece)

11 Cf. Roscher I/1, 1884-1886, cols. 477-493, s.v. 'Ares'; Roscher II/2, 1894-1897, cols. 2385-2438, s.v. 'Mars'; Baumeister I, 1889, 116-121, s.v. 'Ares'; Baumeister II, 1889, 885f., s.v. 'Mars'; Daremberg - Saglio 1904, 1607-1623, s.v. 'Mars'; Seyffert 1964, 60-61, s.v. 'Ares'; Tripp 1972, 70-72, s.v. 'Ares'; Hammond - Scullard 1978, 103f., s.v. 'Ares'.

12 See, for example, Boardman - Dörig - Fuchs - Hirmer 1967, P1. 208 (above: from east frieze of the Parthenon on the Athenian Acropolis); Bieber 1967, Figs. 103-105; Stewart 1977, Pl. 48 (a, b, c).

13 See, for example, Reinach 1903, 67, Pls. 81-82; Reinach 1908, 179 (1, 2); Reinach 1920, 55 (1- top, first from the left); Brilliant 1974, 177 (Fig. IV.17); Hanfmann n.d., Fig. 112.

14 See Plin. HN 36.26: nunc vero praeter supra dicta quaeque nescimus Mars etiamnum est sedens colossiaeus eiusdem manu in templo Bruti Callaeci apud circum eundem (...). "As it is, apart from the works mentioned above and those unknown to us, there is furthermore the colossal seated statue of Mars by the same artist [i.e.: Skopas] in the temple built by Brutus Callaecus, also in the Circus (...)”. (Trans. D. E. Eichholz, Loeb Classical Library, No. 419, X, London-Cambridge [Mass.] 1962). 


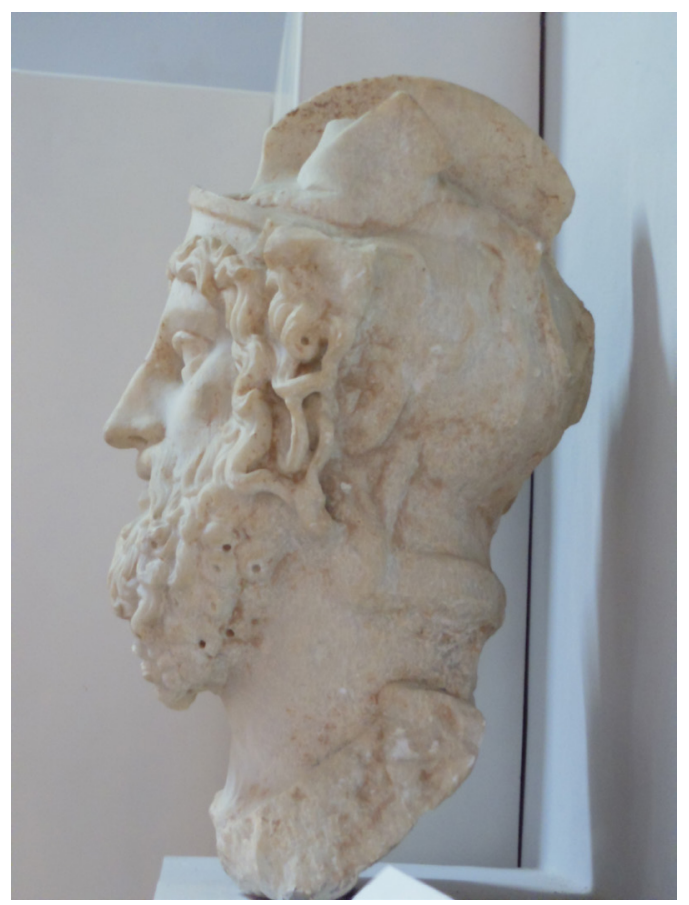

Fig. 3. Profile view of the head - left side (Asher Ovadiah; courtesy of the Superintendency of Antiquities of Euboea, Greece)

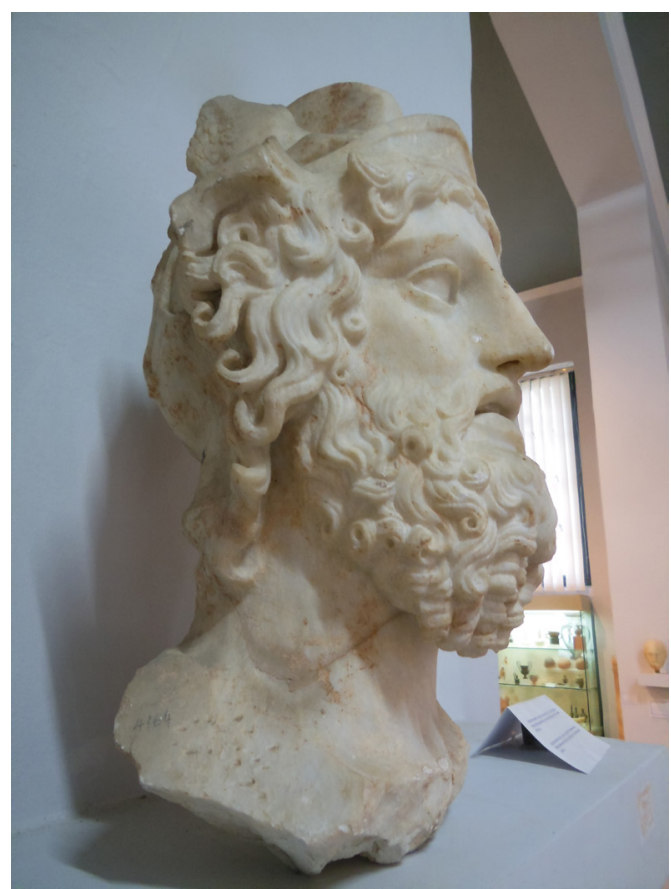

Fig. 4. Profile view of the head - right side (Asher Ovadiah; courtesy of the Superintendency of Antiquities of Euboea, Greece) 


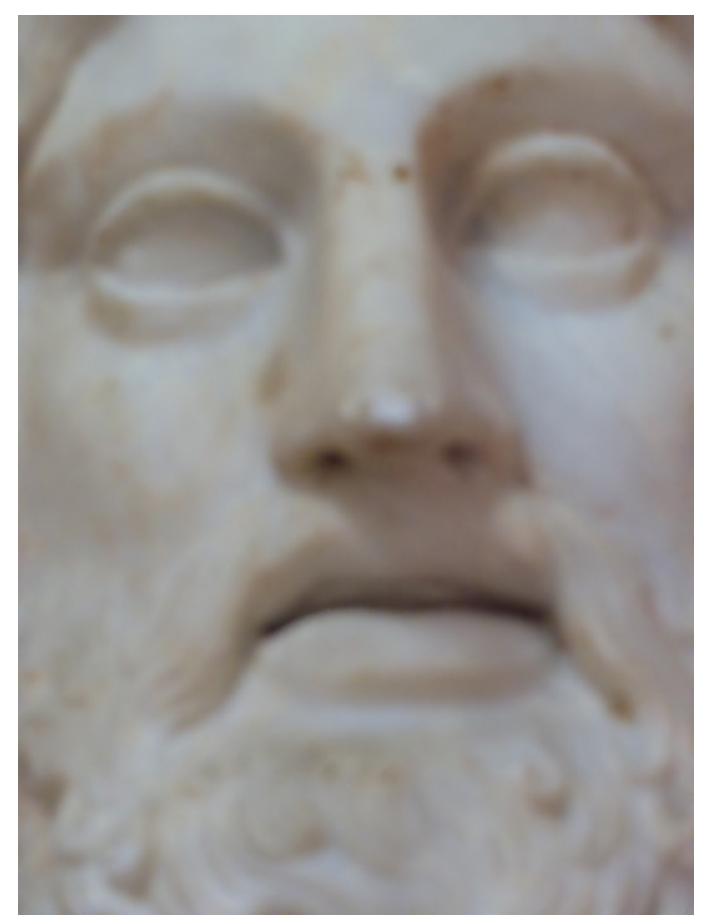

Fig. 5. Facial details (Asher Ovadiah; courtesy of the Superintendency of Antiquities of Euboea, Greece)

\section{Dating}

The head in question thus seems to be a Roman copy of the god Ares, ${ }^{15}$ whose artistic treatment was inspired by Classical-Hellenistic Greek sculpture. The anonymous Roman sculptor, who displays a high degree of technical ability, adopted artistic and stylistic elements of the $4^{\text {th }}-2^{\text {nd }}$ centuries BCE, especially those close to the Skopadic trend. The head appears to be a pre-Hadrianic copy of a Greek original from the $4^{\text {th }}-2^{\text {nd }}$ centuries $\mathrm{BCE}$, featuring the theatrical-pathetic characteristics of the Skopadic approach.

\section{References}

Avi-Yonah, M. (1969): A History of Classical Art, Jerusalem (Hebrew).

Baumeister, A. (1889): Denkmäler des Klassischen Altertums zur Erläuterung des Lebens der Griechen und Römer in Religion, Kunst, und Sitte, I-II, Leipzig.

Bieber, M. (1967): The Sculpture of the Hellenistic Age, New York.

Boardmann, J. - Dörig, J. - Fuchs, W. - Hirmer, M. (1967): The Art and Architecture of Ancient Greece, London.

15 For the image of Ares/Mars in general and that in Greek and Roman sculpture in particular, see also LIMC II/12, 1984: s.v. 'Ares/Mars', 479-580, Figs. 5-542. 
Brilliant, R. (1974): Roman Art from the Republic to Constantine, London.

Daremberg, Ch. - Saglio, E. (1904): Dictionnaire des antiquités grecques et romaines, III/2, Paris.

De Ridder, A. - Deonna, W. (1968 [1927]): Art in Greece, London.

Hammond, N. G. L. - Scullard, H. H. (eds.), (1978²): The Oxford Classical Dictionary, Oxford.

Hanfmann, G. M. A. (n. d.): Roman Art, New York.

Johansen, F. (1992): Greek Portraits, Ny Carlsberg Glyptotek, Copenhagen.

Kalamara, P. - Kosma, M. - Boukaras, K. - Chairetakis, Y. (2015): The City of Chalkis: Chalkis - Euripus - Negroponte - Ĕgriboz, Athens.

Lawrence, A. W. (1972): Greek and Roman Sculpture, London.

LIMC: Lexicon Iconographicum Mythologiae Classicae, II/1-2, Zürich-München, 1984.

Lullies, R. - Hirmer, M. (1960): Greek Sculpture, London.

Müller, W. (1973): Der Pergamon - Altar, Leipzig.

Reinach, $\mathrm{S}$.

(1903): Recueil de têtes antiques idéales ou idéalisées, Paris.

(1908): Répertoire de la statuaire grecque et romaine, II/1, Paris.

(1920): Répertoire de la statuaire grecque et romaine, III, Paris.

Richter, G. M. A. (1984): The Portraits of the Greeks, Oxford (abridged and revised by R. R. R. Smith).

Ridgway, B. S. (2001): Hellenistic Sculpture, I, The Styles of ca. 331-200 B.C., Madison (WI).

Roscher, W. H.

(1884-1886): Ausführliches Lexikon der Griechischen und Römischen Mythologie, I/1 Leipzig.

(1894-1897): Ausführliches Lexikon der Griechischen und Römischen Mythologie, II/2 Leipzig.

Seyffert, O. (1964): Dictionary of Classical Antiquities, Cleveland-New York (revised and edited by H. Nettleship and J. E. Sandys)

Smith, R. R. R. (1991): Hellenistic Sculpture, London.

Stewart, A. F. (1977): Skopas of Paros, Park Ridge (NJ).

Tripp, E. (1972): The Handbook of Classical Mythology, London. 